\title{
FAKTOR-FAKTOR YANG MEMPENGARUHI TINGKAT KEMISKINAN DI SULAWESI UTARA
}

\author{
Jusak Salayang \\ Olly Esry Harryani Laoh \\ Gene H. M. Kapantow
}

\begin{abstract}
This study aims to analyze the factors that influence poverty levels in North Sulawesi. This research was conducted for three months from February to April 2018. The data used were secondary data obtained from the Central Bureau of Statistics, North Sulawesi Province and also from local bookstores, the internet through Google Scholar, to access scientific journal articles and thesis from other universities related to factors that influence poverty levels. Data collected in this study using data from January 2005 to December 2016 and presented in table form are then described and analyzed using multiple linear regression analysis. The results of the study show that the unemployment variable is a factor that significantly influences the level of poverty in North Sulawesi Province. While the level of education, the growth of Gross Regional Domestic Product (GRDP) and inflation did not significantly influence the level of poverty. ${ }^{\text {glimkteprmm* }}$
\end{abstract}

Keywords: poverty, education, unemployment, Gross Regional Domestic Product (GRDP), inflation, multiple linear regression analysis, North Sulawesi

\section{ABSTRAK}

Penelitian ini bertujuan untuk menganalisis faktor - faktor yang mempengaruhi tingkat kemiskinan di Sulawesi Utara. Penelitian ini dilaksanakan selama tiga bulan dari bulan Februari sampai dengan bulan April 2018. Data yang digunakan berupa data sekunder yang diperoleh dari Badan Pusat Statistik, Provinsi Sulawesi Utara dan juga dari toko buku lokal, internet melalui google cendekia, untuk mengakses artikel jurnal ilmiah dan skripsi dari perguruan tinggi lain yang berkaitan dengan faktor-faktor yang mempengaruhi tingkat kemiskinan. Data yang dikumpulkan dalam penelitian ini menggunakan data dari Januari 2005 sampai dengan Desember 2016 dan disajikan dalam bentuk tabel kemudian dideskripsikan dan dianalisis dengan menggunakan analisis regresi linear berganda. Hasil penelitian menunjukkan bahwa variabel pengangguran merupakan faktor yang berpengaruh secara signifikan terhadap tingkat kemiskinan di Provinsi Sulawesi Utara. Sedangkan tingkat Pendidikan, pertumbuhan Produk Domestik Regional Bruto (PDRB) dan inflasi tidak berpengaruh signifikan terhadap tingkat kemiskinan. "ghmk+eprm*

Kata Kunci : kemiskinan, pendidikan, pengangguran, pertumbuhan Produk Domestik Regional Bruto (PDRB), inflasi, analisis regresi linear berganda, Sulawesi Utara

\section{PENDAHULUAN}

\section{Latar Belakang}

Indonesia kini terdapat berbagai permasalahan yang menyangkut mengenai kehidupan bermasyarakat, antara lain masalah kemiskinan,pengangguran, lingkungan hidup dan lain-lain. Permasalahan tersebut timbul akibat terjadinya ketidak merataan hasil pendapatannya.
Pada alinea ke empat Pembukaan Undang-Undang Dasar 1945 tercantum tujuan pembangunan nasional dari negara Indonesia, yaitu untuk memajukan kesejahteraan umum. Dengan meningkatkan kinerja perekonomian agar mampu menciptakan lapangan pekerjaan dan menata kehidupan yang layak bagi seluruh rakyat Indonesia. Sehingga sasarannya adalah menurunkan tingkat kemiskinan yang ada. 
Kemiskinan muncul ketika seseorang atau sekelompok orang tidak mampu mencukupi tingkat kemakmuran ekonomi yang dianggap sebagai kebutuhan minimal dari standar hidup tertentu. Kemiskinan lahir bersamaan dengan keterbatasan sebagian manusia dalam mencukupi kebutuhannya. Kemiskinan telah ada sejak lama pada hampir semua peradaban manusia. Kemiskinan merupakan masalah yang paling kompleks yang terjadi hampir semua negara di dunia. Kemiskinan juga merupakan masalah multidimesional. Artinya, bukan hanya menyangkut masalah ekonomi tetapi juga sudah menyangkut ke masalah sosial, budaya dan politik.

Berbagai kondisi yang mendiskripsikan masyarakat miskin seperti masih banyak anakanak menderita kekurangan gizi, tingkat kesehatan yang buruk, tingkat buta huruf yang tinggaldi lingkungan yang buruk dan masi kurangnya akses infrastruktur maupun pelayanan publik. Daerah kantong-kantong kemiskinan tersebut menyebar di seluruh wilayah indonesia dari dusun-dusun di dataran tinggi, masyarakat tepian hutan, desa-desa kecil yang miskin, masyarakat nelayan ataupun daerah-daerah kumu di perkotaan. Dan sebagian besar pendapat manusia mengenai kemiskinan pada intinya mereka berpendapat bahwa kemiskinan mengambarkan sisi negatif.

Sehingga permasalahan yang paling besar yang selalu terjadi di Sulawesi Utara adalah permaslahan kemiskinan di mana dengan adanya kemiskinan menyebabkan ekonomi masyarakat menurun dan pendapattan masyarakat juga menurun, berbicara kemiskinan di Sulawesi Utara, biasanya ada yang menyebabkan terjadinya kemiskinan atau ada faktor-faktor yang mempengaruhi tingkat kemiskinan di Indonesia faktor- faktor tersebut adalah :

1. Kurangnya penguasaan teknologi

2. Pendidikan

3. Investasi

4. Pengangguran

5. Upah minimum

6. Pertumbuhan ekonomi

7. Demokrasi

8. Inflasi

9. Penganguran terbuka

10. Pendapatan
Sulawesi Utara merupakan salah satu provinsi di Indonesia yang tak pernah lepas dari masalah kemiskinan. Hal ini dikarenakan hampir semua kabupaten kota yang ada di provinsi ini memiliki penduduk miskin. Berikut ini tabel jumlah penduduk miskin dan persentase yang ada di Sulawesi Utara.

Tabel 1. Jumlah Penduduk Miskin dan Persentasenya di Sulawesi Utara

\begin{tabular}{lccr}
\hline No & Tahun & $\begin{array}{c}\text { Jumlah Penduduk Miskin } \\
\text { (ribu / jiwa) }\end{array}$ & Persentase (\%) \\
\hline 1. & 2012 & 177,40 & 7,63 \\
2. & 2013 & 201,10 & 8,50 \\
3. & 2014 & 197,56 & 8,26 \\
$4 .$. & 2015 & 208,54 & 8,64 \\
5. & 2016 & 202,82 & 8,34 \\
\hline \multicolumn{2}{l}{ Sumber $:$ BPS Propinsi Sulawesi Utara }
\end{tabular}

Tabel 1, menunjukkan bahwa persentase penduduk miskin di Propinsi Sulawesi Utara periode tahun 2005- 2016 mengalami fluktuasi. Pada tahun 2016, mengalami penurunan untuk jumlah penduduk miskin dibandingkan deng nan tahun sebelumnya menjadi $8,3 \%$. Secara bertahap pemerintah Provinsi Sulawei Utara sudah melakukan upaya-upaya untuk mengurangi jumlah pendudukmiskin. Pelaksanaan programprogram pro-rakyat dan memberikan fasilitas yang memadai agar mampu memenuhi dan mengakses berbagai pelayanan kebutuhan masyarakat. Sehingga penulis tertarik untuk meneliti tentang faktor-faktor yang mempengaruhi tingkat kemiskinan di Sulawesi Utara.

\section{Rumusan Masalah}

Berdasarkan uraian latar belakang permasalahan di atas, dapat diketahui bahwa di Provinsi Sulawesi Utara, angka kemiskinan setiap Tahun nya memiliki perubahan - perubahan, itu berarti setiap tahun nya pemerintah sudah dapat berupaya untuk mengurangi tingkat kemiskinan di Sulawesi Utara tetapi kembali naik lagi tingkat kemiskinan pada tahun 2016. Angka kemiskianan yang tinggi ini mengakibatkan semakin banyak nya tingkat kemiskinan di Sulawesi Utara.

Besarnya Tingkat kemiskinan dipengaruhi oleh berbagai hal antara lain adalah Tingkat Pendidikan, pengangguran, pertumbuhan PDRB dan Inflasi. Oleh karena itu, diperlukan analisis mengenai tingkat kemiskinan di Provinsi Sulawesi Utara yakni untuk mengetahui faktor - fakror yang mempengaruhi tingkat kemiskinan di Provinsi Sulawesi Utara. 
Atas dasar permasalahan tersebut maka maka pertanyaan penelitian yang akan dipecahkan dalam penelitian ini adalah : Bagaimana pengaruh faktor tingkat Pendidikan, tingkat penganggura, pertumbuhan PDRB dan inflasi terhadap tingkat kemiskinan di Provinsi Sulawesi Utara?

\section{Tujuan Penelitian}

Tujuan dari penelitian adalah untuk menganalisis faktor-faktor yang mempengaruhi tingkat kemiskinan di Provinsi Sulawesi Utara.

\section{Manfaat Penelitian}

Manfaat dari penelitian ini adalah sebagai berikut :

Bagi Masyarakat adalah dengan adanya penulisan ini dapat membantu masyarakat untuk lebih mengetahui faktor - faktor apa saja yang mempengaruhi kemiskinan di Sulawesi Utara, dan masyarakat juga dapat mengantisipasi faktor faktor yang membuat terjadi nya kemiskinan sehingga dapat membantu generasi yang akan datang.

Bagi Pemerintahadalah di mana dengan adanya penulisan ini dapat memberikan motivasi baru bagi para pemerintah untuk lebih mengetahui bagai mana cara menangulangi tingkat kemiskinan di Selawesi Utara, sehingga dapat menguranggi tingkat kemiskinan di Sulawesi Utara.

\section{METODE PENELITIAN}

\section{Waktu dan Tempat Penelitian}

Penelitian ini dilaksanakan KUR PT. Bank Mandiri (Persero) Tbk KC Manado Dotulolong Lasut (nasabah). Selama empat bulan dari bulan September sampai dengan Desember 2016 yang dimulai dari persiapan sampai penyusunan laporan penelitian.

\section{Metode Pengumpulan Data}

Dalam penelitian ini, data yang digunakan adalah data sekunder dimana data sekunder adalah data yang diperoleh dari pihak lain (sudah tersedia) yaitu data yang diperoleh dalam bentuk jadi dan telah diolah oleh pihak lain, yang biasanya dalam bentuk publikasi. Jenis data yang digunakan adalah time series (rutun waktu). Sumber data yang di peroleh dari Badan Pusat Statistika (BPS) Provinsi Sulawesi Utara.

\section{Konsep Operasional Variabel Penelitian}

Dalam penelitian ini digunakan dua jenis variabel, yaitu variabel dependen (terikat) dan variable independen (bebas)

1. Tingkat Kemiskinan (\%)

2. Pendidikan di ukur dengan lamanya bersekolah (Tahun)

3. Tingkat Pengangguran (\%)

4. Tingkat Pertumbuhan PDRB atau Laju pertumbuhan PDRB (\%)

5. Tingkat Inflasi (\%)

\section{Variabel Terikat (Dependent Variable)}

Variabel terikat yang di gunakan dalam penelitian ini adalah tingkat kemiskinan, yaitu jumlah penduduk miskin, yang ada di Sulawesi Utara.

\section{Variabel Bebas (Independent Variable)}

Dalam penelitian ini yang menjadi variabel bebas adalah:

a. Lamanya bersekolah (X1)

Pendidikan merupakan jumlah penduduk yang menempuh pendidikan. Sebagai indikator pendidikan digunakan lama sekolah). Umur penduduk berusia 15 sampai 25 tahun. Adapun satuan dari variabel pendidikan ini adalah Tahun.

b. Pengangguran (X2)

Pengangguran merupakan jumlah menganggur atau tingkat pengangguran, yang termasuk angkatan kerja namun tidak melakukan pekerjaan atau sedang mencari kerja. Variabel jumlah pengangguran yang digunakan adalah jumlah pengangguran terbuka yang terjadi di Provinsi Sulawesi Utara dengan Tingkat pengangguran.

c. Pertumbuhan PDRB (X3)

Tingkat pertumbuhan PDRB merupakan gambaran pertumbuhan ekonomi suatu wilayah/region tertentu. PDRB (Produk Domestik Regional Bruto) merupakan nilai tambah yang dihasilkan oleh semua unit usaha dalam suatu wilayah, atau merupakan semua nilai barang dan jasa akhir yang dihasilkan oleh seluruh unit ekonomi dari suatu wilayah dalam jangka waktu satu tahun. Dalam penelitian ini digunakan laju pertumbuhan PDRB Provinsi Sulawesi Utara menggunakan perhitungan yang digunakan oleh BPS. 


\section{d. Inflasi (X4)}

Inflasi merupakan kenaikan harga keseluruhan dan terjadi secara berkelanjutan serta mempengaruhi harga barang dan jasa yang lainnya (Boediono, 2001). Tingkat inflasi yang digunakan dalam penelitian ini adalah tingkat inflasi Kota Manado dengan satuan persen.

\section{Metode Analisis Data}

\section{Analisis Regresi Linear Berganda}

Analisis dimaksudkan untuk mengetahui besarnya pengaruh tingkat kemiskinan di provinsi Sulawesi Utara dengan menggunakan Analisis Regresi Linear Berganda.

\section{$Y=a+61$ Pendiditiant 62 Pengangouran +63 Pertumbuhan PDRB +64 Intlasite}

Di mana:

$\mathrm{Y}=$ Tingkat Kemiskinan

$\mathrm{X} 1$ = Pendidikan

$\mathrm{X} 2$ = Pengangguran

$\mathrm{X} 3$ = Pertumbuhan Ekonomi

$\mathrm{X} 4$ = Inflasi

\section{Uji Asumsi Klasik}

\section{Multikolinearitas}

Multikolinearitas adalah sebuah situasi yang menunjukan adanya korelasi atau hubungan kuat antara dua variabel bebas atau lebih dalam sebuah model regresi berganda. Dan jika tidak terjadi korelasi maka dapat melanjutkan ke analisis berikutnya.

\section{Uji F}

Menurut Ghozali dalam Hardiyati (2010) mengatakan bahwa uji $\mathrm{F}$ digunakan untuk mengetahui tingkata signifikansi pengaruh variabelvariabel independen secara Bersama-sama (simultan) terhadap dependen. Dalam penelitian ini, hipotesis yang digunakan adalah :

Ho : variabel-variabel bebas yaitu tingkat pendidikan, tingkat pengangguran, pertumbuhan ekonomi dan tingkat inflasi tidak mempunyai pengaruh yang signifikan secara bersama-sama terhadap variabel terikatnya yaitu kemiskinan.

H1 : variabel-variabel bebas yaitu tingkat pendidikan, pengangguran, pertumbuhan ekonomi dan tingkat inflasi mempunyai pengaruh yang signifikan secara bersama-sama terhadap variabel terikatnya yaitu kemiskinan. Dasar pengambilan keputusan adalah dengan mengunakan $\mathrm{f}$ tabel, yaitu a. Apabila $\mathrm{F}$ hitung < $\mathrm{F}$ tabel, maka H0 diterima dan H1 di tolak. b. Apabila F hitung > F tabel, maka H0 ditolak dan H1 di terima.

\section{Uji t}

Uji t digunakan untuk menguji signifikasi hubungan antara variabel $\mathrm{X}$ dan $\mathrm{Y}$, apakah varibel $\mathrm{X} 1, \quad \mathrm{X} 2, \quad \mathrm{X} 3, \mathrm{X} 4 \quad$ benar-benar berpengaruh terhadap variabel $\mathrm{Y}$ (tingkat kemiskinan) secara terpisah atau parsial.

Hipotesis yang digunakan dalam pengujian ini adalah :

a. Ho : variabel-variabel bebas (tingkat pendidikan, timgkat pengangguran, pertumbuhan ekonomi dan tingkat inflasi tidak mempunyai pengaruh yang signifikan terhadap variabel terikat (tingkat kemiskinan),

b. H1 : Variabel-variabel bebas (tingkat Pendidikan, tingkat pengangguran, pertumbuhan ekonomi dan tingkat inflasi mempunyai pengaruh yang signifikan terhadap variabel terikat (tingkat kemiskinan).

Dasar pengambilan keputusan dengan mengunakan $t$ tabel, yaitu :

a. Apabila $\mathrm{t}$ hitung $>\mathrm{t}$ tabel, maka $\mathrm{H} 0$ di tolak dan H1 diterima.

b. Apabila $\mathrm{t}$ hitung $<\mathrm{t}$ tabel,maka $\mathrm{H} 0$ diterima dan H1 ditolak.

\section{Koefisien Determinasi (R2)}

Koefisien diterima (R2) digunakan untuk mengetahui sejauh mana ketetapan atau kecocokan garis regresi yang terbentuk dalam mewakili kelompok data hasil observasi. Koefisien determinasi mengambarkan bagian dari variasi total yang dapat diterangkan oleh model. Semakin besar nilai R2 (mendekati 1), maka ketetapannya dikatakansemakin baik (Setiawan dan Kusrini 2010).

\section{HASIL DAN PEMBAHASAN}

\section{Deskripsi Daerah Penelitian}

Desa Sea adalah salah satu desa dari 14 desa yang bereada di wilayah Kecamatan Pineleng, Kabupaten Minahasa. Desa Sea terletak pada $1^{\circ}$ $25^{\prime} 40.15^{\prime \prime} \mathrm{U}$ dan $124^{\circ} 48^{\prime} 03.18^{\prime \prime} \mathrm{T}$, dengan ketinggian 284 DPL dan luas kemiringan lahan 316 Ha. Desa Sea memiliki suhu rata-rata $29-32{ }^{\circ} \mathrm{C}$ dan curah hujan 2000-3000 mm. 
Provinsi Sulawesi Utara dengan Ibukota Manado terletak di ujung utara Pulau Sulawesi dan merupakan Provinsi maju di Kawasan timur Indonesia yang juga berada di tepian pasifik yang merupakan Kawasan yang cukup strategis. Kedudukannya membujur dari timur ke barat dengan daerah paling utara adalah kepulauan Sangihe yang secara geografis terletak diantara $00^{\circ} 15^{\prime}-05^{\circ} 34^{\prime}$ lintang utara dan antara $123^{\circ}$ $07^{`}-127^{\circ} 10^{`}$ bujur timur, Provinsi Sulawesi Utara memiliki luas total hanya mencapai 13 ,851.64 (km2) tergolong luas yang kecil dibandingkan dengan total luas pulau Sulawesi. Secara administratif, Provinsi Sulawesi utara terdiri dari atas 11 kabupaten dan 4 kota, administratif pemerintahan kabupaten dan kota ini terdiri atas 167 kecamatan dan 1.951 desa/kelurahan. Sebelum diberlakukannya Undang - undang Nomor 38 Tahun 2000 tentang pemerintah daerah, Sulawesi Utara juga terdiri atas Kabupaten Gorontalo. Namun, sejak diberlakukanya otonomi daerah tahun 2001 kabupaten kabupaten Gorontalo tersebut dihapus dan menjadi provinsi baru yaitu Provinsi Gorontalo.

Batas Provinsi Sulawesi Utara meliputi :

1. Di sebelah utara dengan Laut Sulawesi, Samudera Pasifik dan Republik Filipina

2. Di sebelah timur dengan Laut Maluku

3. Di sebelah selatan dengan Teluk Tomini

4. Di sebelah barat dengan Provinsi Gorontalo

Secara geografis Provinsi Sulawesi Utara memiliki daerah yang bervariasi, mulai dari dataran rendah sampai pegunungan dengan dataran tingginya. Secara umum memiliki iklim tropis dengan suhu rata - rata sekitar $26,6{ }^{\circ} \mathrm{C}$ dan rata - rata curah hujan yang terjadi antara 2000 - $2400 \mathrm{~mm}$ per tahun dengan rata - rata jumlah hari hujan sepanjang tahun adalah 20 hari, dan bulan januari merupakan bulan paling sering hujan yakni 28 hari hujan (BPS Sulawesi Utara, 2015).

Provinsi Sulawesi Utara memiliki 41 buah gunung dengan ketinggian berkisar 1.112 - $1.995 \mathrm{M}$ diatas permukaan laut. Kondisi geologi sebagian besar adalah wilayah vulkanik. Semua vulkanik ini membentuk pegunungan (otogenisa) menghasilkan morfologi yang berbukit - bukit dengan perbedaan relief topografi yang cukup besar. Dari jumlah gunung yang ada tadi adalah beberapa yang masi aktif seperti diantaranya, Gunung Soputan di Minahasa Selatan dengan ketingian mencapai 1.783 M, Gunung Ambang di Kabupaten Bolaang Mangondow, serta Gunung Lokon di Kota Tomohon. memiliki dataran tinggi yang cukup luas, kesuburan tanah yang ada dan keberadaan beberapa gunung api yang masih aktif sehingga menjadikan Sulawesi Utara sebagai salah satu penghasil komoditi pertanian yang seharusnya dapat menjadi sector unggulan.

Potensi pariwisata alam yang dimiliki Provinsi Sulawesi Utara juga cukup besar dan beragam diantaranya potensi pantai - pantai yang ada di Kabupaten Minahasa Utara potensi alam kota Tomohon dan kabupaten minahasa yang meliputi : Danau Linau, Danau Tondano dan masih banyak lagi yang seharusnya dapat menarik wisatawan dari seluruh dunia bukan hanya dari Kawasan tiongkok saja.

\section{Analisis Deskriptif}

Penelitian ini menganalisis faktor faktor yang mempengaruhi kemiskinan di Provinsi Sulawesi Utara. Data yang digunakan mengunakan data rentang waktu analisis mulai tahun 2005 - 2016 mengunakan analisis Regresi Linear Berganda yang bertujuan untuk mengetahui pengaru dari beberapa variabel independent (variabel bebas) terhadap variabel dependen (variabel terikat). Alat pengolahan data yang digunakan dalam penelitian ini adalah perangkat lunak (software) computer SPSS version 21. Maka oleh karena itu perlu dilihat bagaimana gambaran perkembangan secara umum dari tingkat Pendidikan, pengangguran, pertumbuhan PDRB, inflasi dan tingkat kemiskinan.

\section{Tingkat Kemiskinan Sulawesi Utara}

Pemerintah Provinsi Sumatera Utara menjadikan persoalan kemiskinan sebagai fokus utama mereka untuk dituntaskan. Penanggulangan kemiskinan dilaksanakan dalam bentuk penyuluhan dan bimbingan sosial, pelayanan sosial, penyediaan akses kesempatan kerja dan berusaha, penyediaan akses pelayanan kesehatan dasar, penyediaan akses pelayanan pendidikan dasar, pelayanan akses pelayanan 
perumahan dan pemukiman dan/atau penyediaan akses pelatihan, modal usaha dan pemasaran hasil usaha. Berikut ini adalah tabel jumlah dan persentase penduduk miskin di Provinsi Sulawesi Utara. Dapat dilihat pada Tabel 2.

Tabel 2. Tingkat Kemiskinan Sulawesi Utara (\%) Tahun 2005 - 2016

\begin{tabular}{clr}
\hline No & Tahun & Tingkat Kemiskinan \\
\hline 1 & 2005 & 9,34 \\
2 & 2006 & 11,54 \\
3 & 2007 & 11,42 \\
4 & 2008 & 9,8 \\
5 & 2009 & 9,32 \\
6 & 2010 & 9,59 \\
7 & 2011 & 8,46 \\
8 & 2012 & 7,63 \\
9 & 2013 & 8,5 \\
10 & 2014 & 8,26 \\
11 & 2015 & 8,65 \\
12 & 2016 & 8,34 \\
\hline Sumber: BPS Sulawesi Utara
\end{tabular}

Tabel 2 menunjukkan bahwa kemiskinan Sulawesi Utara selama tahun 2005 - 2016 berarti kemiskinan setiap tahun selalu mengalami perubahan-perubahan. Peningkatan kemiskinan paling tinggi pada tahun 2006, yaitu $11,54 \%$ sedangkan kemiskinan paling rendah terjadi pada tahun 2012, sebesar 7,63\%.

\section{Pendidikan Lamanya Bersekolah (Tahun)} Pendidikan adalah untuk mengembangkan potensi peserta didik agar menjadi manusia yang beriman dan bertaqwa kepada Tuhan Yang Maha Esa, berakhlaq mulia, sehat berilmu, cakap, kratif, dan menjadi warga negara yang demokratis, serta bertanggung jawab sehingga dapat dikatakan Pendidikan sangat berperan dalam menangulangi terjadinya kemiskinan. Dengan tabel rata-rata lamanya Bersekolah.

Tabel 3. Lamanya Bersekolah Sulawesi Utara (Tahun)

\begin{tabular}{llr} 
& Tahun 2005-20016 & \\
\hline No & Tahun & Tingkat Pendidikan (Tahun) \\
\hline 1 & 2005 & 8,8 \\
2 & 2006 & 8.80 \\
3 & 2007 & 8,80 \\
4 & 2008 & 8,80 \\
5 & 2009 & 8,82 \\
6 & 2010 & 8,89 \\
7 & 2011 & 8,92 \\
8 & 2012 & 9,00 \\
9 & 2013 & 8,79 \\
10 & 2014 & 8,86 \\
11 & 2015 & 8,88 \\
12 & 2016 & 8,96 \\
\hline
\end{tabular}

Sumber: BPS Sulawesi Utara
Tabel 3 menujukkan bahwa pendidikan dengan lamanya bersekolah setiap tahun selalu mengalami perubahan-perubahan. Rata-rata lamanya bersekolah yang paling tinggi ada pada tahun 2012 sebesar 9,00 tahun sedangkan yang paling rendah pada tahun 2005 sebesar 8,8 tahun.

\section{Tingkat Pengangguran Sulawesi Utara}

Pengangguran adalah seorang yang digolongkan kedalam angkatan kerja dan mencari pekerjaan pada suatu tingkat upah tertentu secara aktif, tetapi tidak dapat memperoleh pekerjaan yang diinginkan. Pengangguran mempunyai hubungan dengan kemiskinan jika seorang menganggur atu tidak bekerja maka seseoang atau sekelompok orang tidak dapat menghidupkan dirinya sendiri atau keluarganya. Tingkat pengangguran dapat dilihat pada Tabel 4 .

Tabel 4. Tingkat Pengangguran Sulawesi Utara (\%) Tahun 2005-2016

\begin{tabular}{llr}
\multicolumn{3}{c}{ Tahun 2005-2016 } \\
\hline No & Tahun & Tingkat Pengangguran \% \\
\hline 1 & 2005 & 14,05 \\
2 & 2006 & 14,62 \\
3 & 2007 & 13,35 \\
4 & 2008 & 10,65 \\
5 & 2009 & 10,65 \\
6 & 2010 & 9,61 \\
7 & 2011 & 10,10 \\
8 & 2012 & 7,98 \\
9 & 2013 & 6,79 \\
10 & 2014 & 7,54 \\
11 & 2015 & 9,03 \\
12 & 2016 & 6,12 \\
\hline \multicolumn{3}{l}{ Sumber: BPS Sulawesi Utara }
\end{tabular}

Tabel 4 menunjukkan bahwa pengangguran Sulawesi Utara selama tahun 2005 - 2016 selalu mengalami penurunan yang baik. Peningkatan pengangguran paling tinggi tahun 2006, 14,05 \% sedangkan pengangguran paling rendah tahun 2016, sebesar $6,12 \%$.

\section{Tingkat Pertumbuhan PDRB}

Merupakan proses kenaikan kapasitas produksi dalam suatu perekonomian secra berkesinambungan menuju arah yang lebih baik yang diwujudkan dalam bentuk kenaikan pendapatan daerah (Produk Domestik Regional Bruto) dalam jangka panjang. Sehingga berhubungan dengan ini pertumbuhan ekonomi merupakan indikator untuk melihat keberhasilan pembangunan dan merupakan syarat bagi, pengurangan tingkat kemiskinan. Jumblah PDRB dengan harga konstan dapat dilihat pada Tabel 5. 
Tabel 5. Tingkat PDRB Dengan Harga Konstan Provinsi Sulawesi Utara (\%) Tahun 2005 - 2016

\begin{tabular}{|c|c|c|}
\hline No & Tahun & Pertumbuhan PDRB \% \\
\hline 1 & 2005 & 5,35 \\
\hline 2 & 2006 & 5,72 \\
\hline 3 & 2007 & 6,47 \\
\hline 4 & 2008 & 10,86 \\
\hline 5 & 2009 & 7,85 \\
\hline 6 & 2010 & 7,16 \\
\hline 7 & 2011 & 7,39 \\
\hline 8 & 2012 & 6,86 \\
\hline 9 & 2013 & 6,38 \\
\hline 10 & 2014 & 6,31 \\
\hline 11 & 2015 & 6,12 \\
\hline 12 & 2016 & 6,17 \\
\hline
\end{tabular}

Tabel 5 menunjukkan bahwa PDRB dengan harga konstan tahun 2005-2016 setidaknya mengalami kenaikan dari pada tahun sebelum nya. Peningkatan PDRB yang paling tinggi tahun 2008, 10,86\% sedangkan PDRB paling rendah tahun 2005 sebesar 5,35\%.

\section{Tingkat Inflasi}

Pengertian inflasi secara umum dapat diartikan sebagai kenaikan harga-harga umum secara terus-menerus dalam suatu periode tertentu sehingga inflasi adalah suatu proses meningkatnya harga-harga secara umum yang berkaitan dengan mekanisme pasar yang dapat disebabkan oleh berbagai faktor, antara lain, konsumsi masyarakat yang meningkat, sampai termasuk juga akibat adanya ketidak lancaran distribusi barang. Jumlah inflasi Kota Manado dapat dilihat pada Tabel 6.

Tabel 6. Tingkat Inflasi Sulawesi Utara (\%) Tahun $2005-2016$

\begin{tabular}{llr}
\hline No & Tahun & Tingkat Inflasi \% \\
\hline 1 & 2005 & 18,73 \\
2 & 2006 & 5,09 \\
3 & 2007 & 10,13 \\
4 & 2008 & 9,71 \\
5 & 2009 & 2,31 \\
6 & 2010 & 6,28 \\
7 & 2011 & 0,67 \\
8 & 2012 & 6,04 \\
9 & 2013 & 8.12 \\
10 & 2014 & 9,67 \\
11 & 2015 & 5,54 \\
12 & 2016 & 0,35 \\
\hline \multicolumn{2}{l}{ Sumber: BPS Sulawesi Utara }
\end{tabular}

Tabel 6 menunjukkan bahwa inflasi Kota Manado setiap tahun selalu mengalami perubahan-perubahan. selama tahun 2005 - 2016. Peningkatan Inflasi yang paling tinggi tahun 2005, $18,73 \%$ sedangkan Inflasi paling rendah tahun 2016 sebesar $0,35 \%$.

\section{Analisis dan Pembahasan}

\section{Hasil Uji Asumsi Klasik Multikolinearitas}

Untuk mengetahui ada tidaknya multikolinearitas dalam penelitian ini menggunakan nilai variance inflation factor (VIF). Berdasarkan hasil analisis menggunaka SPSS menunjukan Tabel 7 dapat menunjukan bahwa tidak terdapat multikolinearitas ganda, antara variabel bebas yang diteliti (VIF < 10).

\section{Hasil Analisis Regresi}

Untuk menguji dari penelitian ini digunakan analisis Regresi linear berganda, sehingga dapat mengetahui pengaruh Pendidikan, Pengangguran, PDRB, Inflasi terhadap Kemiskinan. Berikut hasil perhitungan regresi linear berganda dengan mengunakan SPSS..

\section{$\mathrm{Y}=\mathrm{X} 1+\mathrm{X} 2+\mathrm{X} 3+\mathrm{X} 4$}

\section{$Y=51,51-5,11$ Pendidilkan $+0,36$ Pengangouran-0,06 Pertumbuhan PDRB -0,01 Inflasi}

Setelah dilakukan pengujian pada Hasil analisi Regresi ini, sehingga dapat dilihat atau diketahui faktor yang paling berpengaruh terhadap kemiskinan adalah pengangguran atau X2 (Jika pengangguran naik maka tingkat kemiskinan naik juga) maka dalam hal dapat dijelaskan bahwa secara parsial variabel pengangguran berpengaruh terhadap tingkat kemiskinan.

\section{Hasil Uji Statistik}

a. Uji F-Statistik

Dalam konteks penelitian ini, pengujian secara serentak ini ingin melihat apakah variabel pendidikan (lamanya bersekolah), tingkat pengangguran, pertumbuhan PDRB, dan tingkat inflasi berpengaruh terhadap tingkat kemiskinan. nilai sig $=0,004<0,05$, sehingga Ho ditolak, yang berarti variabel-variabel independent secara Bersama-sama berpengaruh signifikan terhadap variabel dependen.

b. Uji t (Uji Parsial)

Untuk mengetahui pengaruh parsial masingmasing variabel bebas terhadap variabel terikat maka digunakan Uji t. Variabel yang digunakan adalah Pendidika, Pengangguran, PDRB, dan Inflasi yang diukur dalam satuan persen serta penduduk miskin yang diukur dengan dalam satuan jiwa. Hasil pengujian dengan menggunkan SPSS di peroleh hasil pengujian secara parsial. 
1. Pengaruh Pendidikan Terhadap Jumlah Penduduk Miskin.

Pengujian terhadap pengaruh pendidikan terhadap tingkat kemiskinan. Diketahui nilai sig. 0,174 >0,05 maka dapat disimpulkan bahwa Ho diterima dan menolak $\mathrm{Ha}$ artinya tingkat pendidikan tidak berpengaruh terhadap tingkat kemiskinan dengan persentase sebesar $82,6 \%$

2. Pengaruh Jumlah Pengangguran Terhadap Kemiskinan.

Pengujian terhadap pengaruh pengangguran terhadap tingkat kemiskinan. Diketahui nilai sig. 0,003 $<0,05$ maka maka dapat disimpulkan bahwa Ho ditolak dan menerima $\mathrm{Ha}$ artinya tingkat pengangguran berpengaruh terhadap tingkat kemiskinan dengan persentase $99,97 \%$.

3. Pengaruh PDRB Dengan Harga Konstan Terhadap Kemiskinan

Pengujian terhadap pengaruh PDRB terhadap tingkat kemiskinan. Diketahui nilai sig. 0,621 >0,05 maka dapat disimpulkan bahwa Ho diterima dan menolak Ha artinya tingkat pertumbuhan PDRB tidak berpengaruh terhadap tingkat kemiskinan dengan persentase sebesar 37,9\%

4. Pengaruh Inflasi Terhadap Kemiskinan Pengujian terhadap pengaruh Inflasi terhadap tingkat kemiskinan. Diketahui nilai sig. $0,743>0,05$ maka dapat disimpulkan bahwa Ho diterima dan menolak Ha artinya tingkat inflasi tidak berpengaruh terhadap tingkat kemiskinan dengan persentase sebesar $25,7 \%$.

Menurut uji serentak Uji $F$ bahwa terdapat ada signifikan setelah di uji parsial. Uji $t$ yang hanya sifnifikan adalah pengangguran sedangkan yang lain tidak signifikan, tetapi secara pengolahan dapat dilihat pendidikan, pertumbuhan PDRB dan inflasi menunjukkan negatif.

c. Koefisien Determinasi (R2)

Koefisien determinasi (R2) digunkan untuk mengukur kebaikan sesuai model dapat menerangkan variasi variabel terikat nilai R2 dapat di lihat pada tabel berikut. Dari lampiran dapat dilihat bahwa koefisisen determinasi ( $\mathrm{R}$ Square) sebesar 0,864. Hal ini berarti $86,4 \%$ variasi tingkat kemiskinan dapat dijelaskan oleh empat variabel independen, sedangkan sisanya sebesar $18,4 \%$ dijelaskan oleh faktorfaktor yang lain di luar model.

\section{KESIMPULAN DAN SARAN}

\section{Kesimpulan}

Berdasarkan hasil penelitian dan pengujian data yang telah dilakukan maka dapat disimpulkan, dari keempat faktor yakni tingkat Pendidikan, pengangguran, pertumbuhan PDRB, dan inflasi, faktor yang berpengaruh nyata terhadap tingkat kemiskinan di Provinsi Sulawesi Utara adalah tingkat pengangguran, sedangkan tingkat pendidikan, pertumbuhan PDRB, dan inflasi tidak berpengaruh nyata.

\section{Saran}

Berdasarakan hasil penelitian yang dilakukan, maka dapat dikemukakan masukan sebagai berikut:

1. Faktor tingkat pengangguran memiliki pengaruh terhadap tingkat

Kemiskinan di Provinsi Sulawesi Utara, yakni memiliki hubungan negatif dan signifikan. Dengan adanya hubungan peningkatan pengangguran terhadap kenaikan tingkat kemiskinan, tentunya kita harus menitikberatkan kepada pemerintah daerah yang diharapkan dapat lebih banyak membukan lapangan pekerjaan bagi masyarakat yang ada di Sulawesi Utara agar supaya dapat menguranggi tingkat kemiskinan.

2. Untuk penelitian selanjutnya, diharapkan agar menambah lebih banyak variabel - variabel lain yang diduga berpengaruh terhadap tingkat kemiskinan.

\section{DAFTAR PUSTAKA}

Hardiyati, R. 2010. Analisis Pengaruh Kualitas Pelayanan Terhadap Kepuasan Konsumen Menggunakan Jasa Penginapan (Villa) Agrowisata Kebut The Pangilaran. Skripsi fakultas ekonomi universitas Diponegoro. Semarang.

Setiawan dan Dwi E. K. 2010. Ekonometrika. CV . ANDI OFFSET. Yogyakarta. 